\title{
BLACK ELKS SPEAKS: WHAT WAR MEANS TO A NATIVE AMERICAN WARRIOR
}

\author{
by Asih Sigit Padmanugraha \\ Faculty of Languages and Arts State University of Yogyakarta
}

\begin{abstract}
Abstrak
Black Elk Speaks merupakan karya sastra bergenre biografi yang ditulis oleh John G. Neihardt berdasarkan cerita lisan dari Black Elk, seorang Sioux yang hidup pada akhir abad ke-19. Sebagai sebuah epik dalam sastra Indian Amerika, karya ini merefleksikan kebenaran sejarah yang selama ini dihilangkan dalam sejarah Amerika oleh bangsa Kulit Putih. Salah satunya keberadaan perang dan ksatria, yang selalu diidentikkan dengan hal yang negatif dan bersifat merusak. Oleh karenanya, artikel ini berusaha mengekplorasi makna perang yang sesungguhnya bagi ksatria bangsa Indian Sioux di dalam Black Elk Speaks.

Perang memang tidak bisa dipisahkan dengan bangsa Indian karena sudah merupakan tradisi budaya: sebagai inisiasi menuju kedewasaan, membalas dendam, dan mendapatkan status social. Perang ini disebut perang antar suku yang melibatkan para kstaria secara individu dan senjata yang digunakan pun sederhana sehingga tidak merusak, misalnya bila dibandingkan dengan peperangan yang dilakukan oleh bangsa Kulit Putih. Makna perang yang kedua adalah perang dalam mempertahankan wilayah mereka dari invasi Kulit Putih, dalam perang ini mereka melawan tentara Amerika. Selain itu mereka bertahan hidup melawan kelaparan dan juga mempertahankan kelangsungan bangsa Sioux atau bangsa Indian Amerika pada umumnya sebagaimana disimbolkan dalam perlindungan terhadap ibu dan anak-anak.

Pada akhirnya, dalam Black Elk Speaks tercermin bahwa konsep perang dan ksatria bangsa Indian Amerika yang selama ini ada adalah tidak benar sebagaimana digambarkan oleh bangsa Kulit Putih. Justru perang yang dilakukan oleh bangsa Kulit Putih lebih merusak dan berbahaya dan ini terbukti dengan kehancuran bangsa Sioux sebagai benteng terakhir peradaban bangsa Indian di Amerika sebagaimana tercermin dalam Black Elk Speaks.
\end{abstract}

Kata Kunci: BlackElk Speaks, perang, ksatria, bangsa Indian Sioux.

\section{A. INTRODUCTION}

No one would oppose the idea saying that Native Americans play considerable roles in American history. Unfortunately, many American historical documents give a little attention on the American Indians. Einstadt proposes a thought that their existence are frequently absent from the American history (1987:17), and because of which, probably, the stereotyped images of the Indians develop.
Einstadt's suggestion seems to be proper that, especially in popular culture, the Native American's images are to fulfill the white men's need. Bird (1996:2) states that the Native American's myths, such as Pocahontas, are White mainstream myths (1996:2). Furthermore, McDonald in Shape-Shifting: Images of Native Americans in Recent Popular Fiction (2000) and Mary Anne Weston in Native American in the News: Images of Indians in the 
Twentieth Century Press (1996) suggest similar thoughts.

Those images of Native American people and culture build negative stereotypes which are of course not accurate. Negative stereotype also goes to the existence of warrior hood in Native American culture. It is inevitable to say that Native American culture is closely related to war, but what Meyer clarifies in History of the Santee Sioux: United States Indian Policy on Trial (1993) that warrior Indian is considered as "warlike, cruel, barbaric, and destructive" is too much and might be misleading.

Numerous scholarly writings that raise issues and themes related to the study of Native American culture investigate warrior culture. They are developed by scholars of different and separate fields such as history, anthropology, and folklore. Up till now, the writer does not find the investigation of such theme in literary studies. Therefore, this article tries to reveal what war truly means for a warrior in Native American Culture as reflected in Black Elk Speaks, a biographical work of Black Elk as retold by John G Neihardt.

Black Elk Speaks is an exceedingly significant literary work because Deloria in his foreword states that it is a classic work on the history of the West (Neihardt, xiv). Its importance is further stressed by Olson (Faulkner, 1982:3) who articulates that this work is an epic which, based on the conventional criticism, represents the historical reality. Moreover as a native oral histories, Black Elk Speaks is also a key for understanding how the Native Americans understand the world they fashion and inhabit (Fixico, 1997:17). And a study on the warrior hood in the work would reveal what war accurately means for the Native American warrior. Accordingly, this work is worth studying in order to investigate the Native American culture. Besides, a biographical writing is having some qualifications among other things are: (1) a story told at a particular historical moment is representative of patterns forming the personality of individuals and the character of their culture, (2) individuals (or selected groups of them) typify their entire culture; and (3) the researcher is simply a neutral recorder of factual data (Angrosino, 1989:1). This idea emphasizes the accuracy of interpreting the war and warrior in Native American culture as reflected in Black Elk Speaks. Besides, the analysis is supported by the psychological approach to investigate the motive of the warriors.

\section{B. THE SIOUX \\ 1. The Great Sioux Nation}

Native American people in the United States of America are as different from each other as French, Scots, Poles, English, and Irish; even, they are more diverse (Josephy, 1968:9). Moreover, from the numerous Native American Nations in America, each has its own culture, which is very far different from others. For example, the Native American cultures of the Plains are different from tribes of the Pacific coast, of the Woodlands, of the Great Basin, of the Southeastern United States, and so on, and they, even, are divided into small sub-tribes, one of which is the Sioux.

Black Elk is one of the great leaders of the Oglala Sioux, one sub-tribe of the Sioux, belonging to the Great Sioux Nation, the term of which is applied to denote seven different peoples or tribes that once ruled the very vast area in the northern part of the Great Plains of the United States of America.

The term Sioux itself is a fragment of the French and Ojibwa word nadouessioux. This is generally believed to be a derogatory term meaning "little snakes," which is used to refer to Minnesota Dakota. The seventeenth century French trappers coined it. The name resulted from a history of territorial conflicts between the Sioux and the Ojibwas, who were located to the east of the Sioux (Rice, 1998:6). The term Sioux always refers to one of the three division of it: Dakota, Nakota and Lakota.

Each division prefers the terms Dakota, Nakota, and Lakota, meaning "the allies," when referring to themselves as a people and a nation, for these are the names of the group's different dialects, regions, and economies. (Sioux par 2) 
The Sioux Nation is also known as "Oceti Sakowin" or the "Seven Council Fires." This title is designated to the seven divisions of the nation-Mdewakanton, Sisseton, Teton, Wahpekute, Wahpeton, Yankton, and Yanktonais. Each of these names was derived from a certain characteristic they had or a region they lived in (Walker, 1982:15)

Furthermore Walker (1982:16-17) explains that the Mdewakanton, Wahpekute, Wahpeton, and Sisseton lived close together by a lake known as Spirit or Knife, and were collectively called "knife." The French changed this to Santee. The Santee established themselves in what would later be known as eastern Minnesota.

The Yankton and Yanktonais lived between the Santee and the Teton, and were called the "middle people." The Yankton and the Yanktonais settled on the western border country of what is now Minnesota and South Dakota.

The Teton whose name, tinta, meaning "dweller of the plains," were so numerous that it divided itself into seven sub-tribes. They are: The Oglala, the Brule, the Hunkpapa, the Minneconjou, the Oohenumpa, the Sihasapa, and the Itazipo or Sans Arc (Walker, 1982:19). The Tetons are the strongest between the other two divisions. They are known as the strongest and fiercest tribe of the Plains people especially since they obtained horses and guns.

\section{The Sioux and Oral Tradition}

Tracing the origins of the Sioux Nation has its own specific difficulties. Different from European and Euro-American's culture, the Sioux, like all Native American people, are used to the oral tradition. They use spoken words in the form of legends, speech, folktales, etc., for handing the tradition of their culture from one generation to the next. The oral tradition plays more than a prominent position in Native American culture; it is "the culture itself." (Einhorn, 2000:3). Einhorn also emphasizes that the oral tradition is not just speaking and listening, because what it means is the whole process, which involves a lifestyle - the whole process of the society in terms of its history, its culture, its language, its values, and subsequently, its literature. Therefore, it is not merely a simple matter of speaking and listening, but living that process. Because of this oral tradition, Mails implies that the origins of the Sioux Nation are shrouded in mystery (Mails, 1990:13).

However, the life narratives and stories of the Sioux are representative in exploring the history of the Sioux. The Sioux people have many stories which are told by the older ones to the younger in the tribe. Many important historical events of the tribe are told as stories, and in this way the history of the people is recorded. These stories were not told, however, with the idea of forcing the children to learn, but for pleasure, and they were enjoyed by young and old alike. Perhaps it is because an Indian child is trained to use his ears carefully that his memory is so reliable like explained by Luther Standing Bear in Stories of the Sioux (Bear, 1988:v). The Sioux memories are so reliable that they depend greatly on their memory in their life. Their ability to memorize would be more advanced in the wild life, contrasted to the 'civilization' offered by the Euro Americans (Eastman, 2004:5). Oglala Sioux Four Guns contrasted the Native American oral tradition with the dominant culture's writing tradition. He says, "The Indian needs no writing. Words that are true sink deep into his heart where they remain. He never forgets them. On the other hand, if the white man loses his paper, he is helpless" (Einhorn, 2000:114).

\section{The History of the Sioux}

Some historians propose some speculations that the Sioux once lived in Eastern part of what is now the United States of America, in South Carolina to be exact. It is even unrecorded in the historical accounts that there was a great dramatic change in the Sioux life style as they migrated from the East and settled upon the Great Plains (Mails, 1990:10)

To all intents and purposes, the Sioux are a people who came into being in the late 1600 s, when they first moved as a nation into 
the Midwest and buffalo country or the Great Plains (Mails, 1990:13). The Sioux were first noted historically in the Jesuit Relation of 1640 , when they were living in what is now Minnesota. Until the end of the seventeenth century, all of the Sioux lived in Wisconsin and Minnesota near Lake Superior (The Sioux, 2004)

Their migration had been in a southwesterly direction in the face of the hostile Ojibwas, who had been equipped with guns by Europeans. Emerson Hough, an anthropologist and historian states in Thomas E. Mails' Fools Crow (1990:14)

And, so far from being a meat-eating folk who gladly met all comers in any kind of ring with the hard gloves, the truth about the Sioux is that they originally were planters and not hunters; and that when they got into the forest country of Minnesota they were very thoroughly whipped by the incompetent Chippewas, and so forced westward into Dakota. ....... There was considerable change and not a little evolution on this continent; and the great Sioux migration is only one of many - one marking an entire change in the customs and character of a tribe.

Those statements prove that the Sioux once had lived as farmers and planters in the eastern part of the United States. Because of intertribal warfare against Chippewa or Ojibwa, they were pushed westward. Their life style had been evolving, and they became buffalo hunters.

Before the coming of the White Americans, the Sioux inhabited a large portion of the northern Great Plains. The Crow were directly to the west, Mandan and Hidatsa to the north, and Ponca, Omaha, Pawnee to the south (Through Indian $\mathrm{p}$ 1). Across more than 750,000 square miles, the heartland of the continent was a vast sea of grass, interrupted here and there by mountainous terrain and winding, forested river bottoms. It was so large that from the region's eastern boundary along the Mississippi River, a rider on horseback might travel for weeks before running up against the western wall of the Great Plains, the Rocky Mountains (Through Indian p. 2)

In the mid-18th century, having driven the Cheyenne and Kiowa out of the Black Hills, the Sioux inhabited the North Great Plains and the western prairies - mainly in Wisconsin, Iowa, Minnesota, North and South Dakota, and up into the bordering provinces of Canada. They then numbered at least 30,000 . The Tetons, numbering some 15,000 , were the most populous of the seven tribes, and the Oglala Sioux, the largest group of the Teton, numbered some 3,000. The Sioux had a typical Plains area culture, including buffalo hunting and the sun dance. This cultural change is influenced by the introduction of horses and guns by the Spanish. However, the Teton are mostly the Sioux division who has this culture. The others, the Santee and the Nakota, are not (Mails, 1990:1516).

Their invasion led inevitably to friction and warfare with tribes already located in the vast area. They fought with success the Crows, Kiowas, Poncas, Omahas, Arikaras, and Cheyennes, displacing them all by 1800 . From 1800 to 1830 the Tetons or the Prairie Sioux reigned supreme. Life was good for them. They relaxed, hunted, socialized, and consolidated and they hold over the splendid country they now considered to be permanently their own (The Sioux par 5-6).

\section{THE SIOUX WAR CULTURE \\ 1. Defining War}

Although there are various definitions of war, the followings are considered as the representative ones. Malinowski defines war as " an armed contest between two independent political units, by means of organized military force, in the pursuit of a tribal or national unity" (in Bramson, 1968:247). Meanwhile, Naroll defines war as "public lethal group combat between territorial teams" (in Ferguson, 1984:3). Otterbein proposes a little bit similar definition. He defines a war as "armed combat between political communities" (in Ferguson, 
1984:3). Wallace states another definition. $\mathrm{He}$ says that a war is "the sanctioned use of lethal weapons by members of one society against members of another." (in Ferguson, 1984:3)

However, not all would be satisfying. In addition, the substance of studying war or warfare does not lay on the definition but on the cultural phenomena behind that (Ferguson, 1984:4), like what this article tries to reveal.

\section{Warrior: Some Definitions}

Hornby in Oxford Advanced Learner's Dictionary defines a warrior as a member of a tribe who fights for his tribe (1989:1436). From the definition, it can be implied that warrior is closely related to war or warfare. This assumption leads some scholars to analyze the Indian warfare especially in the Great Plains of the American continent. Thomas Biolsi, in his essay "Ecological and Cultural Factors in Plains Indians Warfare", a chapter of R. Brian Ferguson's Warfare, Culture and Environment (1984:141) analyzes the Plains Indian Warfare in anthropological approach. He finds out that intertribal warfare on the Great Plains of North America is relatively important issue of ecological and cultural factors.

Another anthropological analysis on the warfare of the Great Plains Indians is proposed by Bernard Mishkin in Rank and Warfare among the Plains Indians_(1992). In his study, which is focused on Kiowa Indian society, warfare in Kiowa Society, one of the Plains Indian tribes, is mostly caused by economic motivation. Economic status will determine the status in the society.

Warrior culture could not be separated from warfare and anthropological study is helpful because it investigates the type of behavior, fighting or warfare can be linked with an indefinitely wide range of cultural motives (Bramson, 1968:254). Meanwhile, psychological approach, a discipline studying motivation, perception and learning, suggests that: war is a part of a man's fate, war represents social learning gone awry and man strives continually to maintain in his world a condition of optimal stimulation (Bramson, 1968:13-14).

\section{The Sioux Warrior}

From the definitions mentioned above, the term warrior is analogous to the term warfare, fight, man, honor, and warfare ethics. Previously, it is already mentioned that there are negative stereotypes against the Indians because of their warrior culture, especially the Sioux in nineteenth century America. The Sioux is considered as a "warlike" nation and their culture has been the most destructive and bloodiest.

Warrior hood is one significant part of Sioux culture. The Sioux had a reputation that "they made no concessions, few alliances, and many enemies. They were hated by many and feared by most..." (Hassrick, 1996:57). As a nomadic hunting society, the Sioux were economically independent and relied for their survival on the buffalo. Sioux warrior society held personal honesty in high accord. However, they were under no illusions and recognized that outsiders would not treat them in this manner. In fact, "they assumed that their enemies were as devoted to the cause of tribal power as they were themselves. " (Hassrick, 1996:68)

It was in battle that the Sioux warrior defined himself. Risk in battle was held in the highest regard by Sioux culture and those that engaged in it were awarded prestige and honor. The glory of battle was so ingrained in Sioux culture that it would often take precedence over the more practical activity of hunting. However, it would be a mistake to suggest that the sole purpose of battle for the Sioux warrior was prestige and honor. The expansion of territory was critical to protecting the roaming grounds of the buffalo on which their livelihood depended. The Sioux warrior had to be constantly vigilant for in Sioux society there was no such luxury as a sustained peace. Sioux camps could come under attack by raiding parties on any given night. The threat of attack was such that "Men always slept with their weapons beside them, and it is said that children were trained not to cry lest the noise attract enemies." (Hassrick, 1996:75). The motivations of going into battle were not always virtuous from a modern day perspective. It was 
accepted that "retaliation, defense, conquest, and booty were among the primary motivating causes of Sioux warfare." (Hassrick, 1996:76). An award system was in place for those Sioux warriors who successfully engaged in battle. A 'coup' would be awarded to the warrior for a number of different actions. Some examples of being awarded a 'coup' would be scoring a direct hit on the enemy, saving a friend in battle, or having one's horse wounded in battle. The 'coup' system can be summarized by the statement: "Great social position was accorded the holder of many coups". (Hassrick, 1996:92). The Sioux warrior was indeed motivated and kept focused by this institutionalized award system.

Although warrior hood and warfare are closely related to the Sioux culture, the information on the significance of this culture has been misinterpreted by the white for their own purpose - white supremacy. There are not enough studies trying to explore how significant and important the warriors are in the Great Sioux Nation, or whether this culture is destructive and bloody, or whether there is something good, positive, honorable and even holy beyond the existence of the Sioux warriors.

\section{WHAT WAR MEANS TO SIOUX WARRIORS: PSYCHOLOGICAL EX P L A N A T I O N O F S I O UX INTERTRIBAL WARFARE}

The war is analogous to the warrior. Therefore, the Sioux war against the opposing tribes, such as: the Pawnees, the Crows, the Rees and also the Mandans, involves the warriors of each tribe. The warriors' motives of going to fights are various, and those will be obviously seen by using psychological approach.

Psychology consists of the study of motivation, perception, and learning (Bramson, 1968:14). Fergusson says in his introduction to Warfare, Culture, and Environment that one of the psychological approaches attributes the occurrence of war to the particular values of a culture, as expressed in the motivations of warriors (Fergusson, 1984:14). Based on Fergusson statement, the following discussion will focus on the motives of the Sioux intertribal warfare.

\section{Showing Manhood}

This is interesting to explore the motivation of the Sioux people to go on a warpath. Most of them join in warfare for individual reasons. Therefore, they join in warfare against the opposing tribes in order to get their own personal goals.

To become a great brave is the highest aspiration in Sioux culture. Becoming a warrior by successfully going in warfare means that he has passed a test of manhood (Bear, 1978:39). Of course, if he fails, he is not considered as an honorable man in the Sioux community and a man living in his tribe without respect is living nonentity (Bear, 1978:40).

This kind of motives is clearly seen in the Sioux myth previously described. In the myth entitled The Brave Who Went on the Warpath Alone and Won the Name of the Lone Warrior (2005:87-94), the psychological factors have plays important role in the young Sioux's mind. In this myth, the poor young Sioux is not confident for he is never invited to a war party because of his bad clothes. Because he never joins the war, he never kills even a single enemy and never takes home even a single enemy's horse. Therefore, he does not get an honorable status in the community. As a result, he has no confidence of proposing the idol girl of the village.

Feeling frustrated, he decides to go on warpath alone. Fortunately, after going for about two weeks, he successfully kills two enemies and brings a great herd of horses. They number for about one hundred and ten horses. $\mathrm{He}$ is greatly welcome and honored in a great dance. Finally, he could win the belle of the village, raised as a chief, and the society gave him the Lone Warrior.

This myth shows that the high status and rank an individual can get from a society become the motives of a person to go on a 
warpath and become a warrior. Being a warrior obviously makes someone greatly honored.

\section{Taking Revenge}

One of the reasons that cause the warfare of the Sioux against the other Indian tribes is taking revenge. This revenge is triggered by the death of the member of the tribe. The pattern of the warpath is therefore in each revenge case: one mourned for property as well as persons, and vengeance had to be taken for the loss of either (Mishkin, 1992:59). Seen through psychological perspectives, this kind of motive is to show that they grieve over the losses.

This kind of reason has become the trigger of the Yanktonais warfare against the Rees. The Rees mourn and take revenge to the Sioux people. They want to kill the Sioux who has killed the Bald Eagle, the Rees Chief. This war finally has causes lots of loses on the Rees.

This revenge has also become the cause of the Oglala battle against the horse thief, the Crows. This is described in Black Elk's stories in The Sixth Grandfather, when Black Elk join in Crazy Horse Camp when there was a killing of Crow horse thief. It was told as follows:

Everyone was breaking camp, loading the horses. The day before this a war party had gone out. When the party was half way back their crier was saying: "Yeah-hey." They said: "The Loafers who went to the war party, it has been reported that they have been slain." All the women in this village sent up the tremolo and at this time a big whirlwind came in the camp and knocked some of the trees down and took some tipis down, and stampeded the horses. There was one party, who had not gotten killed and came back alive. The Crows had killed these Loafers of Red Cloud's. The Crows at this time were supposed to attack us but were afraid of our power; this is why they wanted to steal our horses. Just before this the war party, had gone out and had seen the tracks of the Crows. They went to bed and the Crows surrounded them and killed them all but the scout who had gone out scouting. One of the Loafers was trying to fix his gun and one of them had evidently gone out to get some wood for a fire and the Crows had killed them in the acts. This Crow party who killed these Loafers were starting over to steal horses. (qtd. in DeMallie, 1991:167)

From this quotation, it is apparently perceived that the Sioux were satisfied because they had gotten some revenge by killing one of the Crows who had stolen the horses. This revenge could be initiated from the two opposing sides, whether the Sioux or the Crow (in Demallie, 1991:200).

\section{Social Status}

Different from the European military organization, most of the Sioux warrior considers warrior as an individual enterprise. Becoming a warrior means becoming a high rank status in Sioux society.

One becomes a warrior by going on the warpath and doing something which shows his bravery. Every able-bodied boy is taught that he should become a warrior, not only in order to defend himself and his people against hostile persons, but to get honor by doing something against an enemy which required cunning and bravery. When one had accomplished such things, he is entitled to certain decorations and privileges, and he could compose songs in honor of himself, which the women would sing, and the more renowned he is the more often would the women sing his songs.

A warrior is entitled to a seat among the councilors, and his influence in the council is in proportion to his renown as a warrior. The warriors take the lead in all matters pertaining to war parties and raids. Anyone could get up a war party, but he must do it according to certain forms and customs, and the one getting up a war party was the leader of the party, but subject to certain rules and regulations (Walker, 1982: 27).

After going on a warpath coming back home successfully, a warrior would be 
celebrated by a victory ceremony. This ceremony shows how the members of the Sioux society are very proud of the warrior's victory.

The Victory ceremonies centered about the young warriors and everyone was very proud of them. This was because the young hunters and warriors were the protectors of the tribe. To them everyone, young and old, looked for protection. Lives, food, property, and fireside were in their keeping and the cost was theirs even to giving up their lives. For this reason, mothers and sisters joined happily in honoring the braves at these big celebrations (Bear, 1978:25).

Another goal of a warrior is becoming a chief. A warrior has a great qualification that has been proven in a battlefield. Therefore, he has the chance to become the chief in the future. This is because in Sioux society, only the finest would become a chief (Bear, 1978:132). If a chief were a brave and a warrior, then his camp would be large. If he were a coward, then his people would leave him (Walker, 1982:26).

\section{E. Black Elk's Warrior Hood}

In Black Elk Speaks, Black Elk is obviously a true warrior, though he is actually a Sioux Medicine Man. Since his childhood, he has been already involved in warfare. $\mathrm{He}$ experiences the two great wars: in the intertribal warfare and in the Indian Wars. Black Elk's involvement in the intertribal warfare is similar with the common warriors as explained previously in What War Means to Sioux Warriors: Psychological Explanation of Sioux Intertribal Warfare. However, his involvement in the Indian War is more unforgettable in which he witnessed the destruction not only his Sioux people but also the Native American civilization.

Compared to the other Sioux Warrior like Red Cloud and Crazy Horse, he does not only fight but also cooperate with the Whites. In Black Elk Speaks, his involvement in the Indian Wars is caused by his determination to get their people's land back. In fact, he also experiences the terrifying and horrible events that happen to his people.

The soldiers killed as many women and children and men as they could while the people were running toward a bluff. Then they set fire to some of the tepees and knocked the others down (Neihardt, 2004:70)

However, what he has in mind is essentially about not only fight and war but also the lives of women and children. As he says:

"This is a good day to die! Think of the children and the helpless at home!"( Neihardt, 2004:78)

This means that he does not want the women and children treated badly, tortured and finally killed by the soldiers:

"Boys, take courage! Would you see these little children taken away from me like dogs?" (Neihardt, 2004:92)

Nevertheless, he is a cooperative warrior. He makes a sort of agreement for the sake of the Sioux women and children that he finally aggress to the Washington's offers to join in Wild-Wild West Show in Europe. As he says:

"But late in my twenty-third summer (1886), it seemed that there was a little hope. There came to us some Washicus who wanted a band of Ogalalas for a big show that the other Pahuska had." (Neihardt, 2004:166)

His people refuse his step, since they still need him as the great medicine man, and many people are sick due to the wars:

My relatives told me I should stay at home and go on curing people, but I would not listen to them. (Neihardt, 2004:166)

However, he is firmed with his decisions, because he has very strong reasons: 
the lives of the Sioux women and children who will play significant roles in the future Sioux society.

He visits many important places in Europe for the Wild-Wild West Show. He hopes what he does will help the Sioux people from the destruction, because the whites have promised to give annual payment for their people who live in the reservation. He visits Grandmother England (Queen Victoria) or England (Neihardt, 2004:170), Manchester, Paris and Germany (Neihardt, 2004:173).

Unfortunately, what he has planned does not work as he hopes. Like what Red Cloud's well-known declaration:

They [the whites] made us many promises,

more than I can remember. . . .

They never kept but one.

They promised to take our land, and they took it! (Langer, 1996:58)

Red Cloud's statement is evidently true since the Sioux people's conditions are far worse than when he sees before he goes away.

There was hunger among my people before I went away across the big water, because the Wasichus did not give us all the food they promised in the Black Hills treaty. They made that treaty themselves; our people did not want it and did not make it. Yet the Wasichus who made it had given us less than half as much as they promised. So the people were hungry before I went away. (Neihardt, 2004:178)

The worst thing is that there are many people starving and many children are dead from starvation. This pitiful and hopeless condition makes him feel so much guilt.

"Just after I came back, some people asked me to cure a sick person, and I was afraid the power would not come back to me; but it did. So, I went on helping the sick, and there were many, for the measles had come among the people who were already weak because of hunger. There were more sick people that winter when the whooping cough came and killed little children who did not have enough to eat. So it was. Our people were pitiful and in despair." (Neihardt, 2004:179)

What he tries to avoid happens in front of his eyes. In the Butchering at Wounded Knee (part 24) their people are butchered for they try to escape from the reservation to escape from starvation.

By now many other Lakotas, who had heard the shooting, were coming up from Pine Ridge, and we all charged on the soldiers. They ran eastward toward where the trouble began...... Dead and wounded women and children and little babies were scattered all along there where they had been trying to run away. The soldiers had followed along the gulch, as they ran, and murdered them in there. Sometimes they were in heaps because they had huddled together, and some were scattered all along. Sometimes bunches of them had been killed and torn to pieces where the wagon guns hit them. I saw a little baby trying to suck its mother, but she was bloody and dead. (Neihardt, 2004:200)

He is then helpless with the condition. As the leader of the Sioux people, his dream is over along with his nation and his people's dream.

And so it was all over.... I did not know then how much was ended. When I look back now from this high hill of my old age, I can still see the butchered women and children lying heaped and scattered all along the crooked gulch as plain as when I saw them with eyes still young. And I can see that something else died there in the bloody mud, and was buried in the blizzard. A people's dream died there. It was a beautiful dream. (Neihardt, 2004:208) 
He feels a great guilt. As the one to whom the Great Spirit has given a vision for their people, Black Elk returns the destruction of his people to Him as describe the the 1;ast part of Black Elk Speaks: The End of the Dream (part 25):

"With tears running, O Great Spirit, Great Spirit, my Grandfather-with running tears I must say now that the tree has never bloomed. A pitiful old man, you see me here, and I have fallen away and have done nothing...... Grandfather!

"Again, and maybe the last time on this earth, I recall the great vision you sent me. It may be that some little root of the sacred tree still lives. Nourish it then, that it may leaf and bloom and fill with singing birds. Hear me, not for myself, but for my people; I am old. Hear me that they may once more go back into the sacred hoop and find the good red road, the shielding tree! "

We who listened now noted that thin clouds had gathered about us. A scant chill rain began to fall and there was low, muttering thunder without lightning. With tears running down his cheeks, the old man raised his voice to a thin high wail, and chanted: "In sorrow I am sending a feeble voice, O Six Powers of the World. Hear me in my sorrow, for I may never call again. O make my people live!" .............For some minutes the old man stood silent, with face uplifted, weeping in the drizzling rain....In a little while the sky was clear again. (Neihardt, 2004:225)

\section{F. CONCLUSION}

The concept of war and warrior in Native American culture has been misinterpreted by the White people. And this negative stereotype has been developed in their mind for centuries. However, from this article, the truth is revealed. From the analysis, there are two wars in which the Sioux warriors are involved: the intertribal war and the Indian Wars.
In the first kind of war, the warriors go to the war field for some reasons, they are: showing manhood, taking revenge, and social status. This kind of war involves individual warrior and simple weapons, and thus it is less destructive, compared to the bloody war tradition in the Whites' culture.

In the Indian war, the main reason is defending territory form the invasion of the Whites, in which the Sioux warriors fight against the soldiers. Besides, they go to the war field to survive against starvation, and to protect their future symbolized by women and children.

Black Elk, one of the great Sioux warriors, truly speaks of what war means for him. War of the Sioux Indian as reflected in Black Elk Speaks is far away from being destructive as those described by the White people. Precisely, those wars committed by White people are more destructive and dangerous like what he witnesses: the end of the Native American Dream, the end of Native American Civilization.

\section{BIBLIOGRAPHY}

Angrosino, Michael V. 1989. Documents of Interaction: Biography, Autobiography, and Life History in Social Science Perspective. Gainesville, FL: University Press of Florida.

. Stories of the Sioux. 1988. Illustrator. Herbert Morton Stoops. Lincoln, NE: University of Nebraska Press.

Bird, S. Elizabeth. 1996. Dressing in Feathers: The Construction of the Indian in American Popular Culture. Boulder, CO: Westview Press.

Brown, Dee. 1981. Bury My Heart at Wounded Knee: An Indian History of the American West. New York: Washington Square Press.

Donald L. Fixico. Editor. 1997. Rethinking American Indian History. Albuquerque: University of New Mexico Press. 
Dykes, Allred J. C. 1966. Great Western Indian Fights. Lincoln: University of Nebraska Press.

Einhorn, Lois J. 2000. The Native American Oral Tradition: Voices of the Spirit and Soul. Westport, CT.: Praeger Publishers.

Einstadt, Abraham S. 1987. American History: Recent Interpretations. Book I; To 1877. New York: Thomas Y. Crowell Company.

Hassrick, Royal B. 1996. The Sioux: Life and Customs of a Warrior Society. Norman, Oklahoma: Redwood Books.

Hornby, A.S. 1989. Oxford Advanced Learners Dictionary. Oxford: Oxford University Press.

Langer, Howard J. Compiler. 1996. American Indian Quotations. Westport, CT: Greenwood Press.

Mails, Thomas and Chief Eagle, Dallas. 1990. Fools Crow. Lincoln, NE.: University of Nebraska Press.

McDonald, Andrew, Maryann Sheridan. 2000. Shape-Shifting: Images of Native Americans in Recent Popular Fiction. Westport, CT: Greenwood Press.

McLauhin, Marie L. 2005. Myth and Legends of the Sioux. 27" March

$<$ http://etext.lib.virginia.edu/toc/modeng/publi c/MclMyth.html>

Meyer, Roy W. 1993. History of the Santee Sioux: United States Indian Policy on Trial. Lincoln NE: University of Nebraska Press.

Mishkin, Bernard. 1992. Rank and Warfare among the Plains Indians. Lincoln, NE.: University of Nebraska.

Nabokov, Peter. 1991. Native American Testimony: A Chronicle of Indian -
White Relation from Prophecy to the Present, 1492 - 1992. New York: Penguin Group.

"Sioux." 2000. The Columbia Encyclopedia. Sixth Edition. New York: Columbia University Press.

Walker, James R. 1982. Lakota Society. Raymond J. Demallie Editor. Linclon, NE.,: University of Nebraska Press.

Weston, Mary Anne. 1996. Native Americans in the News: Images of Indians in the Twentieth Century Press. Westport, CT: Greenwood.

Eastman, Charles Alexander. 2004. "Indian Boyhood." Electronic Version. University of Virginia. 1999. 3" March. $<$ http://etext.lib.virginia.edu/modeng/ modengE.browse.html>

"The Sioux" 2004. Encyclopedia of North American Indians: on line. Houghton Mifflin Company. 7' May. $<$ http://college.hmco.com/history/read erscomp/naind/html/>

Neihardt, John G. 2004. Black Elk Speaks: Being the Life Story of a Holy Man of the Oglala Sioux. An Electronic Version. 5. J a n u a ry. $<$ www.blackelkspeaks.unl.edu/toc.ht $\mathrm{m}>$

"Through Indian Eyes" 2004. qtd. in Native American Tribes: Interesting Facts \& Legends from the Sioux. 31" March. $<$ http://www.geocities.com/willow1d/ factsiou2.html $>$.

"Sioux". 2004. Microsoft Encarta Online Encyclopedia 2001. 1997-2001 Microsoft Corporation. $7^{\text {th }}$ May $<$ http://encarta.msn.com> 